\title{
Fluvial environment and existing stability condition of the Manahara River, central Nepal Himalaya
}

\author{
*Naresh Kazi Tamrakar ${ }^{l}$ and Ramita Bajracharya ${ }^{2}$ \\ ${ }^{1}$ Central Department of Geology, Tribhuvan University, Kirtipur, Kathmandu, Nepal \\ ${ }^{2}$ Khwapa Engineering College, Purvanchal University, Bhaktapur, Nepal \\ (*Email: ntamrakar@hotmail.com)
}

\begin{abstract}
The Manahara River that is one of the large tributaries of the Bagmati River has been exploited in recent decade. Lateral shifting of river, bank erosion and subsequent destruction of fertile lands and inundation of crop lands during high discharge are some of the problems. Five representative segments of the river were surveyed in detail for existing status of the river applying hydrologic, geomorphologic and sedimentologic analyses in order to recognize stability condition. The first to the fifth segments are classified as F4-, C4-, C4-, B4- and B4-streams characterised by matrix supported gravelly substrates. Streams F4 and B4 are potential to degradation and streams C4 are potential to aggradation. Dimensionless shear stress in all the segments exceed critical dimensionless shear stress even at much lower bankfull condition suggesting greater mobility of the riverbed materials. Schumm's F-factor versus M-factor plots revealed that the 3rd and 4th order streams (B4-streams) are potential to degradation, and 5th order (F4 and C4)) streams are potential to aggradation. The existing channel surveyed in 2006 was compared with the previous channel of 1995 . The results indicate that the meander belt area has grown by $8 \%$ and average meander belt width has increased by $32 \%$. The average lateral shift of meander belt axis has approached $156 \mathrm{~m}$ with maximum shift of $243 \mathrm{~m}$ in C4 stream. The average meander length and the meander belt axis length have extended respectively by $25 \%$ and $2.5 \%$. Meander geometry of the 5 th ordered streams deviates from the stability. All these suggest that the planform geometry of the Manahara River has not been stable. Therefore, systemwide instability exists in the river basin. In order to improve the existing river condition, anthropogenic disturbances should be minimised, and bank protection measures and restriction of riverbed mining should be implemented in $\mathrm{C} 4$ - and $\mathrm{F} 4$-streams before deteriorating the river into severe condition.
\end{abstract}

Keywords: River environment, river stability condition, river classification, meander geometry, central Nepal Himalaya

Received: 8 August 2008

\section{INTRODUCTION}

According to Mackin (1948) an equilibrium river is one whose slope is adjusted over a period of years to provide the velocity required for the transport of loads. Lane (1955) defined that discharge and slope of a river in equilibrium tend to balance bed material load and size. Rosgen (1996) defined stream channel stability as the ability of a stream over time, in the present climate, to transport the sediment and water in such a manner that the stream maintains its dimensions, pattern, and profile without aggrading or degrading. In this respect, a stable river is one that has adjusted its size and slope such that there is no significant aggradation, degradation, or plan-form changes within 50 years and is said to be in the state of dynamic equilibrium. The equilibrium of a river system tends to be disturbed by several factors and once this happens, the stream attempts to reacquire equilibrium by a series of adjustments, which are usually mirrored in aggradation, degradation, or changes in plan-form. These adjustments can transmit throughout the whole watershed and lead to systemwide instability. revision accepted: 10 February 2009

The Manahara River, located in the northeast of Kathmandu and stretched for about $28 \mathrm{~km}$, is one of the largest tributaries of the Bagmati River (Fig. 1). It has a shortheaded high-gradient segment (about $5 \mathrm{~km}$ ), and a long lowgradient downstream segment $(23 \mathrm{~km})$. Since the last decade, new settlements and other developmental activities have encroached its banks. Similarly, excavation of construction materials from its channel has intensified bank erosion enormously (Tamrakar 2004; Bajracharya and Tamrakar 2007; Shrestha and Tamrakar 2007). Sedimentation, channel shifting, and bank erosion are notable events in the middle to the lower segments. Adhikari and Tamrakar (2006) reported high bank erodibility hazard and channel instability in the Bishnumati River, a tributary of the Bagmati River. Lateral shifting of channel and rapid erosion of lower banks of the Mahahara River during a high discharge often destroy cultivated lands (Shrestha and Tamrakar 2007). Whether these phenomena are being caused by local factors or by systemwide instability in the river is an important issue at present to be identified, before planning land for town and constructing any infrastructure in and around the river area. 


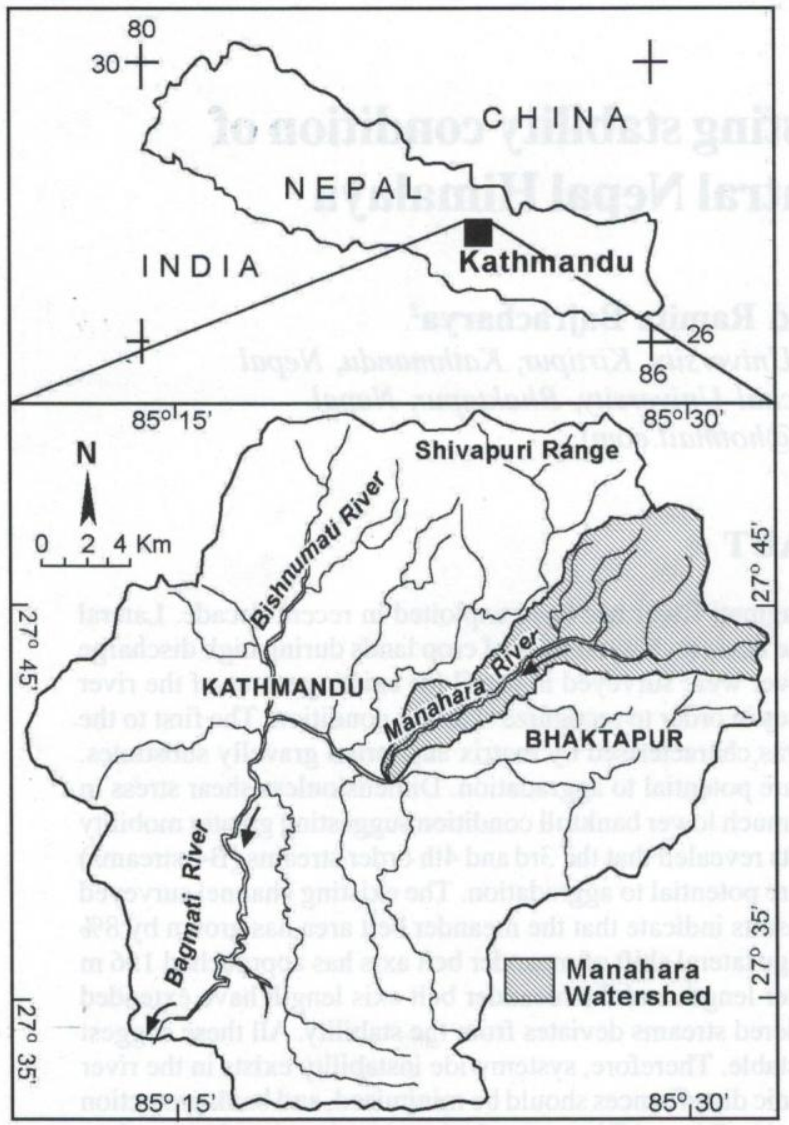

Fig. 1: Location map of study area

Even for protecting the banks and cultivated lands from erosion and inundation, it is a primary goal to firstly recognise existing stability conditions from the information of which the segments to be prioritised and measures to be adopted can be set up.

\section{GEOLOGICAL SETTING}

The Manahara watershed comprises gneisses and granitic pegmatites of the Sheopuri Injection Gneiss Zone (Ohta 1973), and schists and quartzites of the Kulikhani Formation (Stöcklin and Bhattarai 1977) in the northern divide (Fig. 2). It contains metasandstones, siltstones and phyllites of the Tistung Formation (Stöcklin and Bhattarai 1977) in the eastern and southeastern divides. Their foliation generally extends E-W and dips towards the north. The fluvio-lacustrine deposits (Yoshida and Igarashi 1984) cover the central, western, and southwestern parts of the watershed (Fig. 2). The Gokarna Formation comprising gravels, pebbly sands, coarse sands, silts, clays, and lignites crops out in the river between relative heights of 1.5 and $35 \mathrm{~m}$. The Thimi Formation is exposed in the southern region and comprises arkosic sands, silts, and silty clays showing extensive soft sediment deformation structures. The Holocene sediments on the river bars and floodplains range in size from cobble to silt and clay.

\section{METHODOLOGY}

Firstly, regional watershed parameters and river's planform (pattern) were measured on topographic maps (1:25,000 and $1: 10,000)$ and reconnaissance field visits were made along the river. Secondly, five representative segments of the Manahara River (Fig. 3) were selected based on their planform, nature of channel, bank conditions, and vegetation. Then, these segments were surveyed for cross-sections and longitudinal profiles using a levelling instrument, a staff, and a measuring tape. In order to characterise grain size in reach scale and in cross-section scale, Wolman's (1954) pebble counting method was applied in eight transects in each of these five segments. The median grain size obtained from reach-scale counting was applied in stream classification after Rosgen (1994), while the size distribution of the samples from the wetted perimeter of riffle crosssection was considered in evaluating shear stresses. The volumetric bar surface samples were sieved separately for grain size parameters.

Thirdly, the river was surveyed for hydraulic parameters, riparian vegetation, and channel shifting pattern. The existing channel was surveyed in 2006 at 1:10,000 scale to evaluate its plan-form changes. The river segments were classified after Rosgen (1994). Hydraulic and geomorphologic analyses were made and the results were compared with established relationships to diagnose stability conditions of the river.

\section{FLUVIAL ENVIRONMENT}

\section{Relief and drainage system}

The Manahara Basin is elongated in NE-SW direction and covers an area of about $83 \mathrm{~km}^{2}$. High-relief areas surround the basin whereas low-relief areas comprise its central and southwestern parts (Fig. 4a). Drainage texture is fine in the $\mathrm{NE}$ ridges containing bedrock and is very coarse in the SW, in low-lying areas, with a sediment cover (Fig. 4b).

The fourth-order streams (the Sali Nadi, Ghatte Khola, and Mahadev Khola) incise bedrock and terrace deposits. The main stream of the Manahara River is a fifth-order stream (Fig. 3) that has incised the fluvio-lacustrine terrace deposits and has widened the valley, in a geological time, against rising of terraces that have been probably continuing since the late Pleistocene due to neotectonic movements (Bajracharya 1992; Bajracharya 2001). Bajracharya (1992) reported several lineaments, which are still active in the Manahara Basin, and also pointed out that the Charkhande and Manahara faults are responsible for the major westward drift of the Manahara and the Bagmati rivers.

\section{Plan-form geometry}

The sinuosity $(\mathrm{K})$ of meandered Segments 3,4 , and 5 exceeds 1.4 whereas its is less in somewhat straight Segments 1 and 5 (Table 1 ). Segment 2 is potentially prone to lateral accretion with large meander length $\left(\mathrm{L}_{\mathrm{m}}\right)$ and 


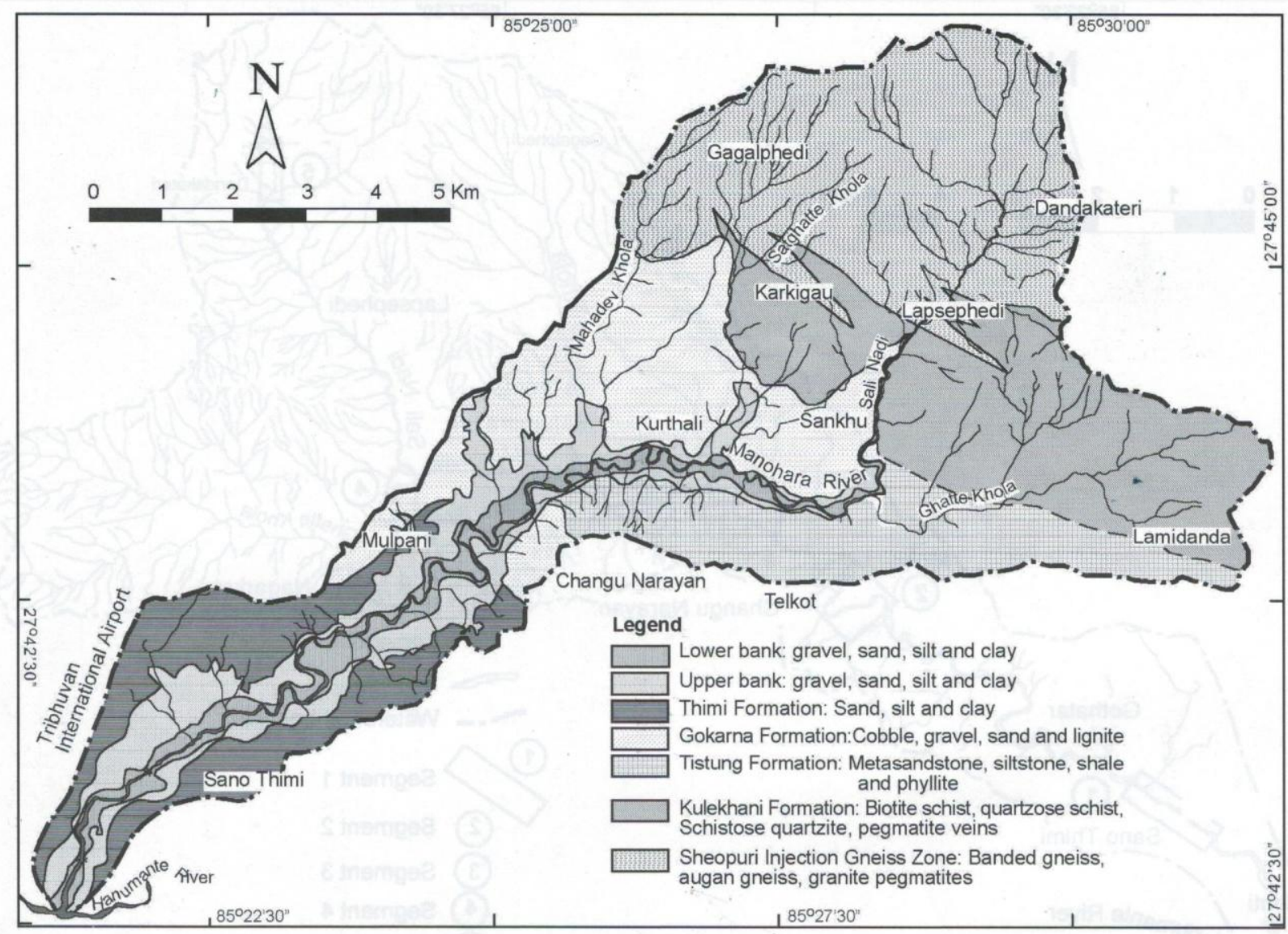

Fig. 2: Geology of the Manahara watershed

meander belt width $\left(\mathrm{W}_{\mathrm{bl}}\right)$. Segments 1,3 , and 4 bear somewhat similar magnitude of $\mathrm{L}_{\mathrm{m}}$ and $\mathrm{W}_{\text {blt }}$. Segment 3 exhibits the highest value of the radius of curvature $\left(\mathrm{R}_{\mathrm{c}}\right)$ and Segment 5 shows the least one.

\section{Plan-form and hydraulic parameters}

In the investigated segments of the Manahara River, riffle and pool cross-sectional areas range from 5.50 to $13.09 \mathrm{~m}^{2}$ and from 0.67 to $2.78 \mathrm{~m}^{2}$, respectively (Table 1 ). The values of width $\left(\mathrm{W}_{\mathrm{bkf}}\right)$, depth $\left(\mathrm{D}_{\mathrm{bkf}}\right)$, maximum depth $\left(\mathrm{D}_{\max }\right)$, and floodprone width $\left(\mathrm{W}_{\mathrm{fpa}}\right)$ are of higher magnitudes in Segments 1 and 2 than those of the remaining segments. The crosssectional areas and width increase from Segment 5 to 2 and then slightly narrow down with increased maximum depth in Segment 1 (Fig. 5).

Segment 1 is entrenched (Table 1; Fig. 5a), Segments 4 and 5 are moderately entrenched, whereas Segments 2 and 3 are slightly entrenched. The width/depth ratio (W/D ratio) progressively becomes greater from Segment 5 to Segment 1 (Table 1; Fig. 5), indicating increased lateral instability towards the downstream segments. Segment 4 possesses the greatest bank height ratio (BHR). The downstream segments posses comparatively low BHR and are vulnerable to lateral shifting of river and flooding.
The meander length ratio varies from 14.75 to 25.98 and in downstream segments it is nearly two times higher than in upstream segments. The meander belt width ratio ranges from 2.01 to 22.9 showing that the middle to lower segments have a large magnitude of meanders, while the upstream segments (i.e., the third- and fourth-order streams) have narrow belts.

\section{Longitudinal profile}

The longitudinal profile of the Manahara River is concave (Fig. 5). The slopes of lower-order streams decline abruptly when the third-order stream begins with a slope of $0.07 \mathrm{~m} / \mathrm{m}$. The slopes of third- to fourth-order streams gradually diminish to $0.014 \mathrm{~m} / \mathrm{m}$. The fifth-order stream shows a gentle slope. Along this portion, Segment 2 possesses the least slope $(0.006 \mathrm{~m} / \mathrm{m})$ and further downstream its slope increases to $0.24 \mathrm{~m} / \mathrm{m}$. Several knick points exist particularly in fourthorder segments.

\section{Hydraulic characteristics}

\section{Mannings's roughness coefficient}

The Manning's roughness coefficient (n) was calculated from Cowan (1959) and correction factors were estimated from Aldridge and Garrett (1973). The n-values are 0.04 in 


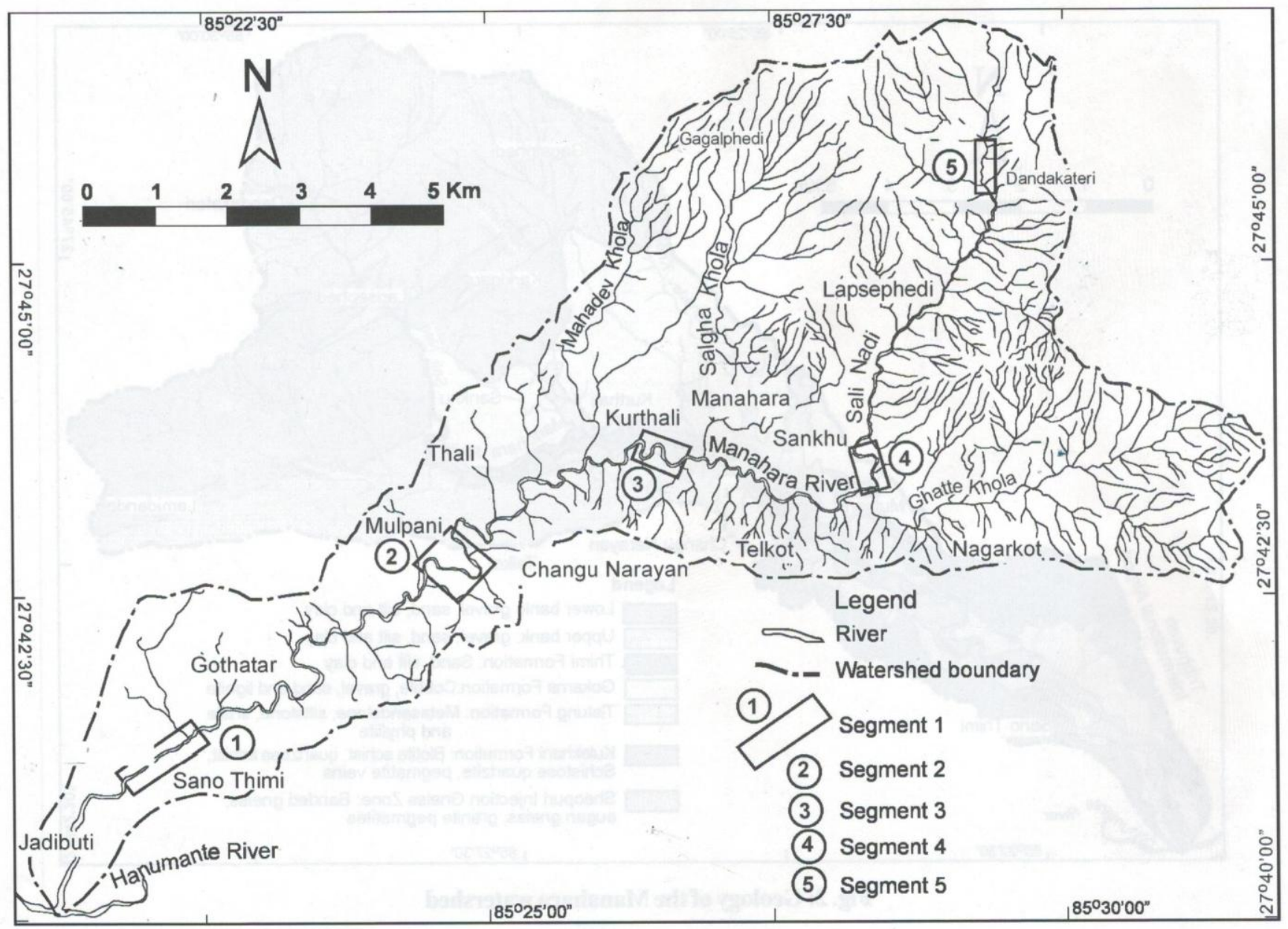

Fig. 3: Five surveyed segments
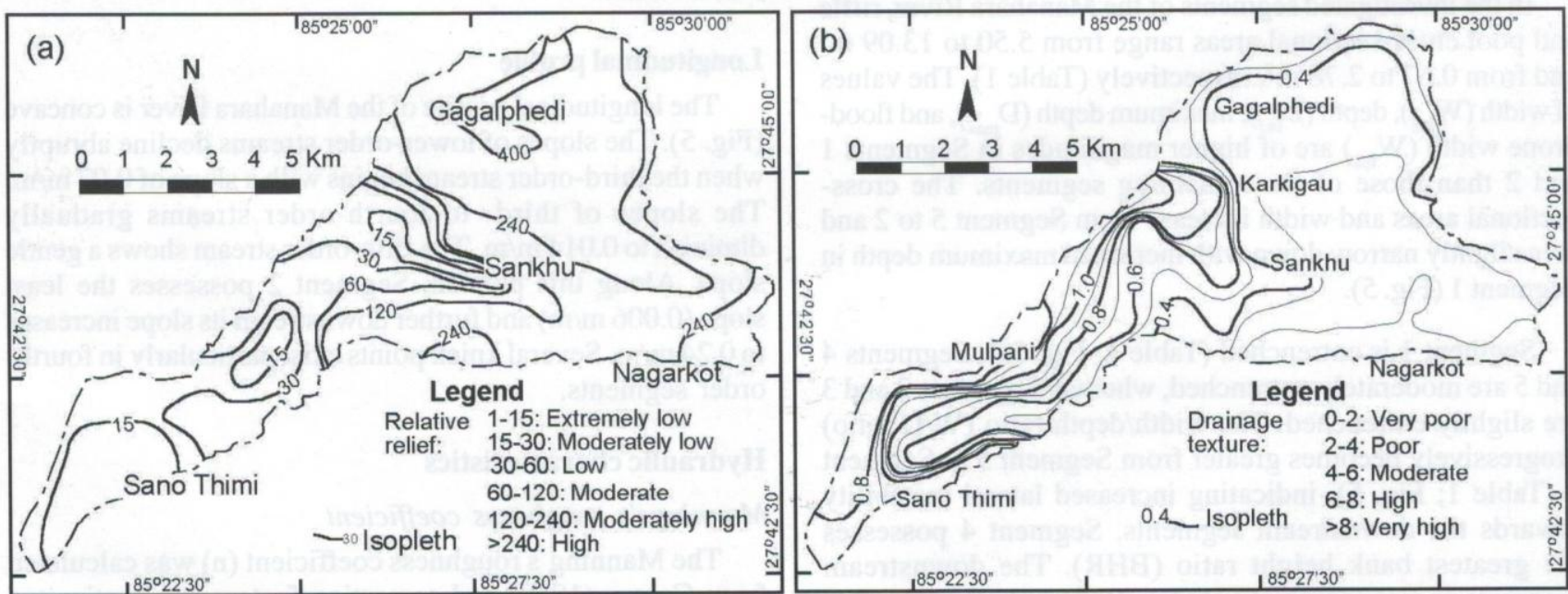

Fig. 4: Isopleths of morphometric parameters of the Manahara watershed. (a) Relative relief and (b) Drainage texture 
Fluvial environment and existing stability condition of the Manahara River

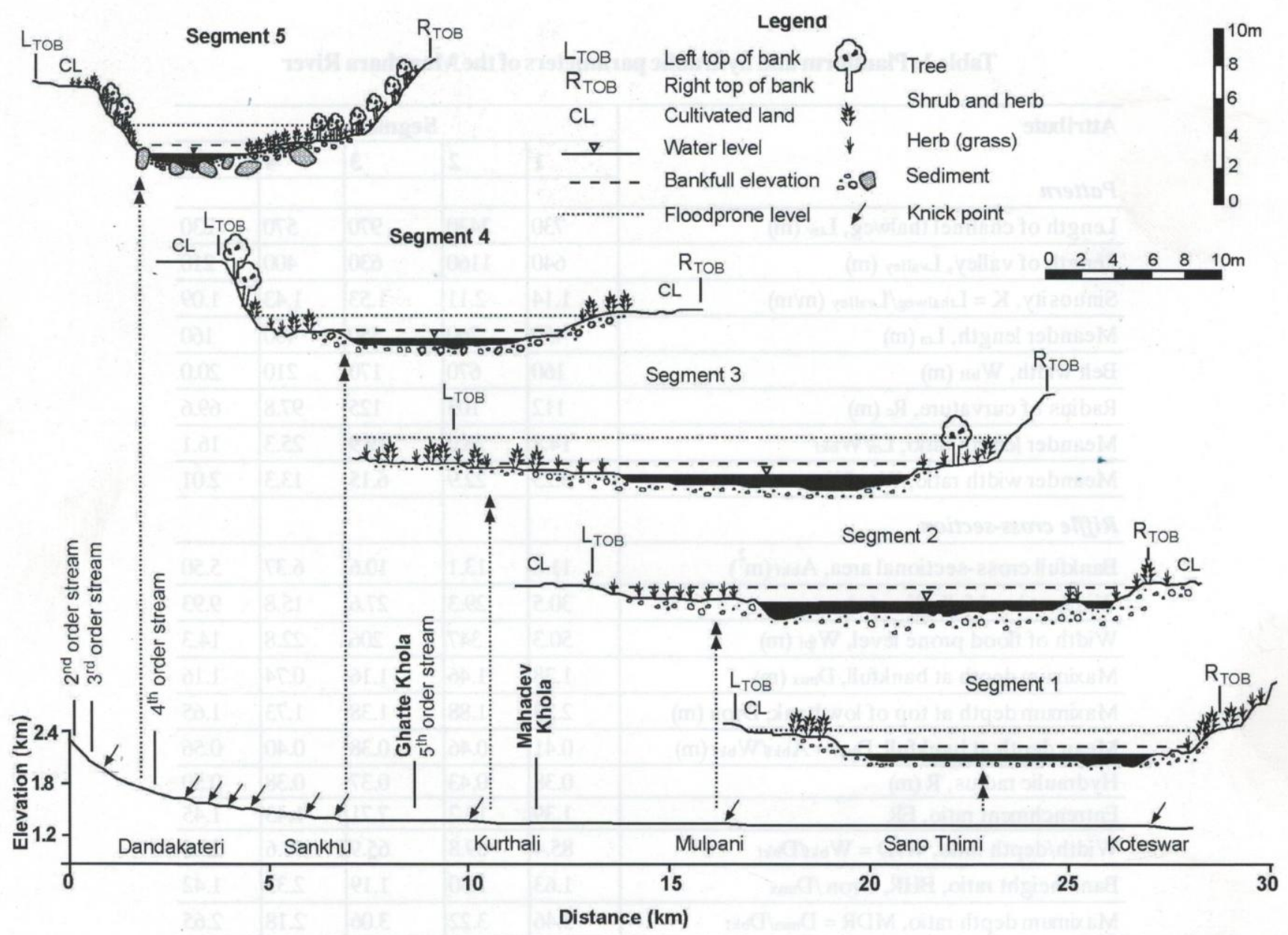

Fig. 5: Longitudinal profiles of the Manahara River and its five study segments

Segments 1, 2, and 3; 0.05 in Segment 4; and 0.13 in Segment 5 (Table 2). A higher n-value in Segment 5 (caused by coarse gravel, wood debris, vegetation in channel, and variation of channel cross-section) would affect discharge in this segment. A low n-value in downstream segments probably supports a high-velocity flow indicating a possibility of bank erosion.

\section{Bankfull discharge and velocity}

The Manahara River is a perennial river fed by springs and storm flows. Generally, rainfall is high between June and September and is lean during November-February. No record of discharge is available, as no gauging station is established in this river. The discharge of the river changes seasonally and it is expected to be high during a high rainfall period.

Bankfull discharge (Q) and velocity (V) were estimated using the following Manning's equation (Chow 1959) and continuity equation, respectively:

$$
\begin{aligned}
& Q=\left(A R^{2 / 3} S^{1 / 2}\right) / n \\
& V=Q / A
\end{aligned}
$$

where $\mathrm{A}$ is the cross-sectional area at bankfull stage, $\mathrm{S}$ is average channel slope, $\mathrm{R}$ is hydraulic radius, and $\mathrm{V}$ is bankfull velocity. The discharge thus estimated varies from $6.95 \mathrm{~m}^{3} / \mathrm{s}$ in Segment 5 to $25.19 \mathrm{~m}^{3} / \mathrm{s}$ in Segment 1 (Table 2) showing a downstream increase of discharge probably due to an increase in cross-sectional area of stream and a decrease in $\mathrm{n}$-value. The discharge may also increase upon the increase of drainage area and the contribution from different tributaries.

The bankfull velocity is highest $(2.13 \mathrm{~m} / \mathrm{s})$ in Segment 1 , medium (1.26-1.27 m/s) in Segments 3, 4, and 5, and least $(1.04 \mathrm{~m} / \mathrm{s})$ in Segment 2. Increased discharge due to increased slope, low roughness, and low meandering probably generate a high-velocity flow in Segment 1 . Considering Segment 2, though the discharge increases in this segment, the velocity is not so large as compared to the other segments, because the increased channel cross-sectional area has probably influenced the velocity therein.

\section{Stream sediments}

The median diameter of reach-scale pebble counts falls on fine to medium gravel categories (Table 2). The $d_{50}$ of the 
Naresh Kazi Tamrakar and Ramita Bajracharya

Table 1: Planiform and hydraulic parameters of the Manohara River

\begin{tabular}{|c|c|c|c|c|c|}
\hline \multirow{3}{*}{$\begin{array}{l}\text { Attribute } \\
\text { Pattern } \\
\end{array}$} & \multicolumn{5}{|c|}{ Segment } \\
\hline & \multirow[t]{2}{*}{1} & \multirow[t]{2}{*}{2} & \multirow[t]{2}{*}{3} & \multirow[t]{2}{*}{4} & \multirow[t]{2}{*}{5} \\
\hline & & & & & \\
\hline Length of channel thalweg, $\mathrm{L}_{\mathrm{w}}(\mathrm{m})$ & 730 & 2430 & 970 & 570 & 230 \\
\hline Length of valley, Lvalley (m) & 640 & 1160 & 630 & 400 & 210 \\
\hline Sinuosity, $\mathrm{K}=\mathrm{L}$ halweg $/ \mathrm{Lvalley}(\mathrm{m} / \mathrm{m})$ & 1.14 & 2.11 & 1.53 & 1.43 & 1.09 \\
\hline Meander length, $\mathrm{Lm}(\mathrm{m})$ & 450 & 760 & 550 & 400 & 160 \\
\hline Belt width, W blt (m) & 160 & 670 & 170 & 210 & 20.0 \\
\hline Radius of curvature, $R_{c}(\mathrm{~m})$ & 112 & 103 & 125 & 97.8 & 69.6 \\
\hline Meander length ratio, $\mathrm{Lm} / \mathrm{W}_{\text {bkf }}$ & 14.8 & 26.0 & 19.9 & 25.3 & 16.1 \\
\hline Meander width ratio, $\mathrm{W}_{\mathrm{blt}} / \mathrm{W}_{\mathrm{bkf}}$ & 5.25 & 22.9 & 6.15 & 13.3 & 2.01 \\
\hline \multicolumn{6}{|l|}{ Riffle cross-section } \\
\hline Bankfull cross-sectional area, $\mathrm{Abkf}\left(\mathrm{m}^{2}\right)$ & 11.8 & 13.1 & 10.6 & 6.37 & 5.50 \\
\hline Width at bankfull, $\mathrm{W}_{\text {bkf }}(\mathrm{m})$ & 30.5 & 29.3 & 27.6 & 15.8 & 9.93 \\
\hline Width of flood prone level, $\mathrm{W}_{\mathrm{fpl}}(\mathrm{m})$ & 50.3 & 347 & 206 & 22.8 & 14.3 \\
\hline Maximum depth at bankfull, $\mathrm{D}_{\max }(\mathrm{m})$ & 1.38 & 1.46 & 1.16 & 0.74 & 1.16 \\
\hline Maximum depth at top of low bank, Dтов (m) & 2.23 & 1.88 & 1.38 & 1.73 & 1.65 \\
\hline Mean depth at bankfull, $D_{b k f}=A_{b k f} / W_{b k f}(m)$ & 0.41 & 0.46 & 0.38 & 0.40 & 0.56 \\
\hline Hydraulic radius, $\mathrm{R}(\mathrm{m})$ & 0.38 & 0.43 & 0.37 & 0.38 & 0.50 \\
\hline Entrenchment ratio, ER & 1.39 & 12.2 & 7.71 & 1.43 & 1.45 \\
\hline Width/depth ratio, $\mathrm{W} / \mathrm{D}=\mathrm{W}_{\mathrm{bkf}} / \mathrm{D}_{\mathrm{bkf}}$ & 85.4 & 69.8 & 65.9 & 47.6 & 24.8 \\
\hline Bank height ratio, BHR, Dтов $/ \mathrm{D}_{\max }$ & 1.63 & 1.30 & 1.19 & 2.33 & 1.42 \\
\hline Maximum depth ratio, $\mathrm{MDR}=\mathrm{D}_{\max } / \mathrm{D}_{\mathrm{bkf}}$ & 3.46 & 3.22 & 3.06 & 2.18 & 2.65 \\
\hline \multicolumn{6}{|l|}{ Pool cross-section } \\
\hline Pool cross-sectional area, $\mathrm{A}_{\text {pool }}\left(\mathrm{m}^{2}\right)$ & 1.98 & 2.61 & 2.78 & 0.67 & 0.73 \\
\hline Pool width, $\mathrm{W}_{\text {pool }}(\mathrm{m})$ & 16.6 & 15.4 & 12.7 & 6.65 & 3.55 \\
\hline Pool maximum depth, D pool (m) & 0.42 & 0.71 & 0.74 & 0.38 & 0.65 \\
\hline 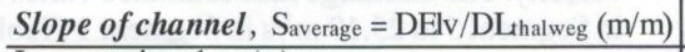 & 0.024 & 0.006 & 0.011 & 0.030 & 0.070 \\
\hline Largest size, $\mathrm{d}_{\max }(\mathrm{m})$ & 0.084 & 0.099 & 0.145 & 0.183 & 1.020 \\
\hline Coarse $90^{\mathrm{th}}$ percentile size, d90 $(\mathrm{m})$ & 0.021 & 0.018 & 0.034 & 0.049 & 0.071 \\
\hline Median size of riffle sediment, $\mathrm{d}_{50}(\mathrm{~m})$ & 0.003 & 0.002 & 0.002 & 0.012 & 0.001 \\
\hline Median size of bar sediment, $\mathrm{d}_{\mathrm{s} 50}(\mathrm{~m})$ & 0.004 & 0.003 & 0.007 & 0.01 & 0.195 \\
\hline Boundary shear stress, $\left(\mathrm{N} / \mathrm{m}^{2}\right)$ & 8.860 & 2.430 & 4.114 & 5.362 & 34.86 \\
\hline Threshold dimensionless shear stress & 0.021 & 0.019 & 0.021 & 0.021 & 0.20 \\
\hline Dimensionless shear stress & 0.254 & 0.080 & 0.073 & 0.067 & 0.298 \\
\hline Threshold depth, Dt (m) & 0.030 & 0.101 & 0.107 & 0.056 & 0.337 \\
\hline Threshold slope, $\mathrm{S}_{\mathrm{t}}(\mathrm{m} / \mathrm{m})$ & 0.002 & 0.001 & 0.003 & 0.004 & 0.047 \\
\hline $\mathrm{D} / \mathrm{D}_{\mathrm{t}}$ & 13.6 & 4.6 & 3.5 & 7.1 & 1.7 \\
\hline $\mathrm{S} / \mathrm{S}_{\mathrm{t}}$ & 12.5 & 4.3 & 3.5 & 6.8 & 1.5 \\
\hline
\end{tabular}


Fluvial environment and existing stability condition of the Manahara River

Table 2: Summary of classification of the Manahara River based on Rosgen (1994)

\begin{tabular}{l|r|r|r|r|r}
\hline \multicolumn{1}{c|}{ Attribute } & Segment 1 & Segment 2 & Segment 3 & Segment 4 & Segment 5 \\
\hline Entrenchment ratio, ER & $1.39(\mathrm{~F}, \mathrm{G})$ & $12.22(\mathrm{C}, \mathrm{E})$ & $7.71(\mathrm{C})$ & $1.43(\mathrm{~B})$ & $1.45(\mathrm{~B})$ \\
\hline W/D ratio & $85.42(\mathrm{~F})$ & $69.77(\mathrm{C})$ & $65.87(\mathrm{C})$ & $47.59(\mathrm{~B})$ & $24.78(\mathrm{~B})$ \\
\hline Sinuosity, K (m/m) & $1.14(\mathrm{~A})$ & $2.11(\mathrm{C}, \mathrm{E})$ & $1.53(\mathrm{C}, \mathrm{E})$ & $1.43(\mathrm{~B})$ & $1.09(\mathrm{~B})$ \\
\hline Slope $(\mathrm{m} / \mathrm{m})$ & $0.024(\mathrm{~F})$ & $0.006(\mathrm{C})$ & $0.011(\mathrm{C}, \mathrm{E})$ & $0.030(\mathrm{~B})$ & $0.070(\mathrm{~B})$ \\
\hline Bed material, median size $(\mathrm{m})$ & 0.002 & 0.002 & 0.003 & 0.015 & 0.007 \\
\hline Rosgen stream type & $\mathrm{F} 4$ & $\mathrm{C} 4$ & $\mathrm{C} 4$ & $\mathrm{~B} 4$ & $\mathrm{~B} 4$ \\
\hline Manning's roughness coefficient, $\mathrm{n}$ & 0.037 & 0.041 & 0.043 & 0.049 & 0.13 \\
\hline Bankfull discharge, $\mathrm{Q}\left(\mathrm{m}^{3} / \mathrm{s}\right)$ & 25.19 & 13.61 & 13.32 & 8.122 & 6.956 \\
\hline Bankfull velocity, $\mathrm{V}(\mathrm{m} / \mathrm{s})$ & 2.130 & 1.040 & 1.256 & 1.275 & 1.260 \\
\hline
\end{tabular}

riffle samples falls on very coarse sand to fine gravel, and $d_{9}$ (coarse fraction retained at 90 th percentile) extents from 0.071 to $0.049 \mathrm{~m}$ (Table 1). The proportion of gravel is almost equal to the proportion of matrix in sand or mud up to Segment 3 and then the amount of gravel increases in the upstream portion of the river probably because of the proximity to the source rocks where slopes and boundary shear stresses are high enough to carry larger fractions.

\section{EXISTING RIVER CONDITIONS}

\section{Stream categories}

The following five morphological characteristics (Rosgen 1994): ER, W/D ratio, K, bed material, and slope were used for classifying the stream segments of the Manahara River. Segments 1, 2, 3, 4, and 5 are classified as the 'F4', 'C4', 'C4', 'B4', and 'B4' stream types, respectively (Table 2).

\section{'F4' stream type}

Segment 1 is entrenched $(<1.4)$ with a high W/D ratio $(>12)$ and somewhat a low sinuosity $(>1.2)$. Its bed material is of pebble-size grade. This segment gradually narrows down with reduced ER. Point bars, point bars with a few mid channel bars, and side bars characterise the deposition pattern (Table 3 ). Riparian vegetation is lean and narrows down with decreasing matrix of grasses, shrubs, cultivated crops, and a few patches of trees (Fig. 6a). The surface water is acidic (pH $=5.96)$ and possesses a high electrical conductivity $(\mathrm{EC}=$ $21600 \mu \mathrm{S} / \mathrm{m}$ ), and a low clarity (visibility $=5 \mathrm{~m}$ ).

There are also riverbed and bank erosion problems (Fig. 6a). The major disturbances recorded are bank encroachment, riparian vegetation clearing, riverbed excavation for construction materials (Fig. 6b), and effluents discharged from settlement areas.

\section{'C4' stream type}

Segments 2 and 3 are less entrenched (Fig. 5) with a W/ $\mathrm{D}$ ratio greater than 12 . These are highly sinuous with very gentle slopes. The bed material is composed of fine gravel. Abundant point bars and mid channel bars constitute depositional channel elements. Riparian vegetation is represented by grasses, shrubs, and cultivated lands of matrix in Segment 2 (Figs. 6c and 6d) and in Segment 3 (Fig. $7 a)$. However, corridors of grass and shrubs growing on top of banks obstruct the river in Segment 3. Both segments possess wide flood-prone areas. Surface water is slightly basic $(\mathrm{pH}=7.2-7.5)$ and bears an intermediate $\mathrm{EC}(8300 \mu \mathrm{S} /$ $\mathrm{m}$ ) and clarities ranging from 9 to $10 \mathrm{~m}$, exhibiting better conditions than those of Segment 1. The banks frequently exhibit erosion scars (Fig. 6d; Figs. 7a and 7b) and in places landslides. Channel shifting is quite remarkable. Cultivation of banks and bars, grazing, and river mining activities are the main notable disturbances.

\section{'B4' stream type}

Segments 4 and 5 are moderately entrenched with a large W/D ratio (Fig. 5). Segment 4 is somewhat meandering but Segment 5 is slightly straight. Slopes of both segments are large. The bed material consists of gravel. Side bars and a few point bars constitute the channel elements. In Segment 4 , the matrix of grass and shrubs, and discontinuous corridors of trees represent the riparian vegetation (Fig. 7c). The left bank of Segment 5 is a cultivated terrace whereas the right bank is a weathered bedrock covered by a thick matrix of grasses, shrubs, and trees (Fig. 7d). A narrow corridor of shrubs and trees borders the cultivated land from the channel. Therefore, these segments have greater canopy than others.

Erosion scars are commonly found on steep and high banks showing mass failures. Riparian vegetation is often constricted for cultivation. Grazing activity is also noticed. However, the stream habitat is in a good condition as indicated by aquatic lives, a high water clarity $(12 \mathrm{~m})$, slightly alkaline water $(\mathrm{pH}=7.3)$, and a low EC $(6700 \mu \mathrm{S} / \mathrm{m})$.

\section{Vertical stability}

BHR indicates a degree of incision that river undergoes relative to its depth, while ER indicates a degree of incision with respect to the flood-prone area. Large BHR increases instability of banks against failure. Banks of the river become 

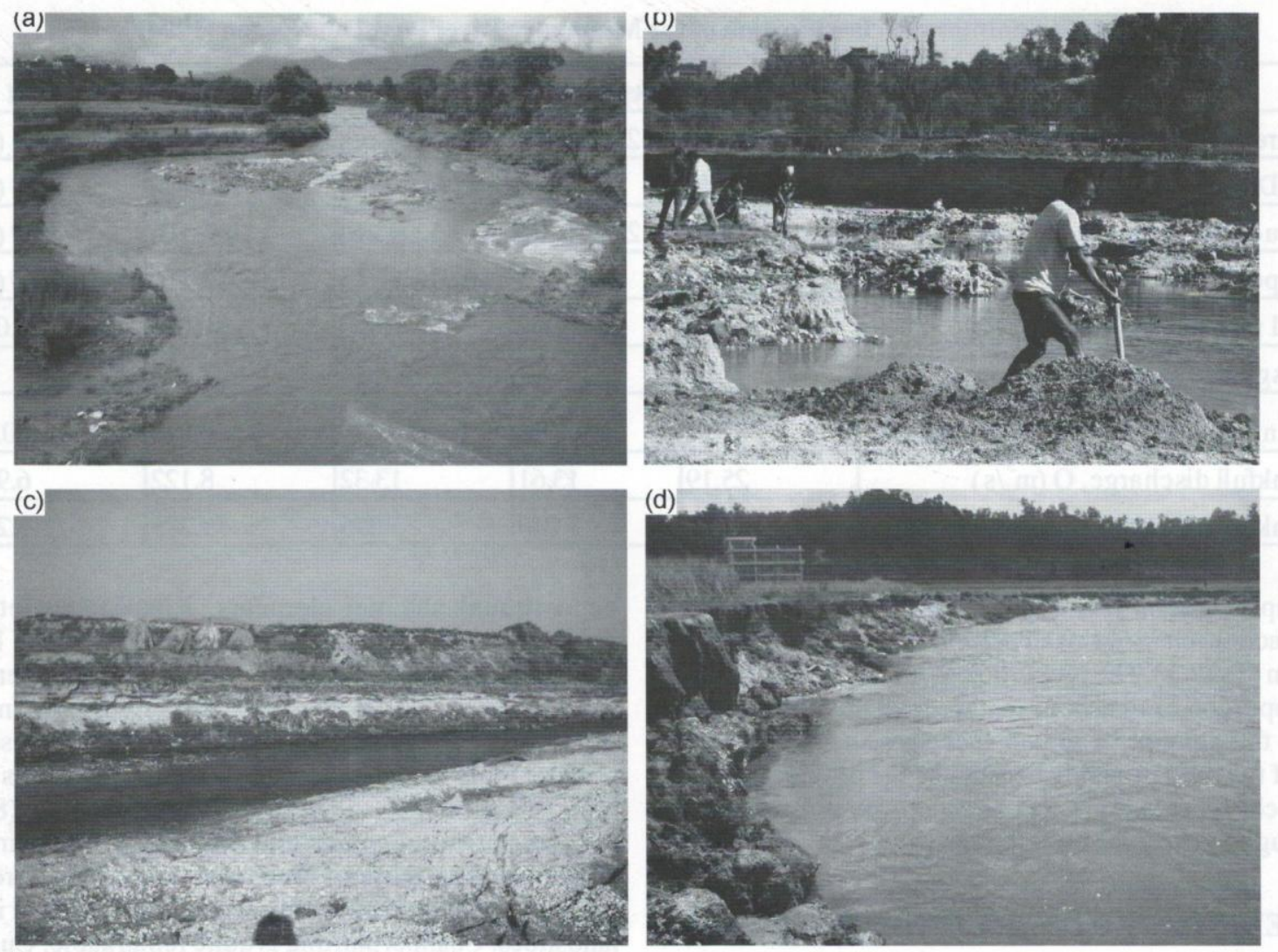

Fig. 6: Photographs showing: (a) channel widening due to lateral erosion as seen from Sano Thimi bridge towards downstream, (b) riverbed excavation for construction material, (c) erosion scar in the right bank of Segment 2, vegetation pattern and bank material, and (d) downstream view of Segment 2 indicating bank erosion and riparian vegetation.

highly unstable when BHR exceeds 1.5 (Rosgen 2001). Banks of Segments 1 and 4 are highly unstable (Table 3). Banks of Segments 2 and 5 are unstable and those of Segment 3 are moderately unstable. The entrenched streams have ER values less than $1.4 \pm 0.2$ (Rosgen 1994). In this respect, Segments 1,4 and 5 are vertically unstable.

\section{Lateral stability}

MWR and W/D provide information on lateral stability of a channel. These ratios indicate lateral confinement on two different scales. High MWR values show vast lateral shifting of a channel. A high W/D ratio is associated with intense bank erosion and channel widening (Rosgen 1996). The values of MWR show that Segments 2 and 3 are vulnerable to lateral instability. Segments 1 and 4 are moderately stable, and Segment 5 is the most laterally stable. Considering the W/D ratio, all the segments are vulnerable at different degrees to bank erosion depending on bank material involved, vegetation cover, and BHR.

\section{Flow competence}

The boundary shear stress is the shear stress generated by flowing stream over its substrate. The boundary shear stress was obtained using the expression of Shields (1936):

$$
\mathrm{t}=\gamma R S
$$

where $\gamma$ is the density of water $\left(1,000 \mathrm{~kg} / \mathrm{m}^{3}\right), \tau$ is the boundary shear stress $\left(\mathrm{N} / \mathrm{m}^{2}\right), \mathrm{R}$ is the hydraulic radius $(\mathrm{m})$, and $\mathrm{S}$ is the channel slope $(\mathrm{m} / \mathrm{m})$.

The boundary shear stresses in Segments 1 and 5 are much greater than those of the remaining segments (Table 1).

Shields (1936) showed that the hydraulic conditions required for entrain particles could be explained by the dimensionless shear stress or Shields constant, $\tau_{i}^{*}$ as below:

$$
\tau_{i}^{*}=D S /\left(s_{s}-1\right) d_{i}
$$

where $d_{i}$ is the particle diameter which is coarser than ith \% of the riverbed material and $s_{s}$ is the specific gravity of sediments (2.65).

Bradley and Mears (1980) used Shields constant between 0.45 and 0.06 for computation of bedload transport using Shields criteria. As the dimensionless shear stress varies with bed material size distribution, for armored beds, Andrews (1983) derived the relationships as below: 

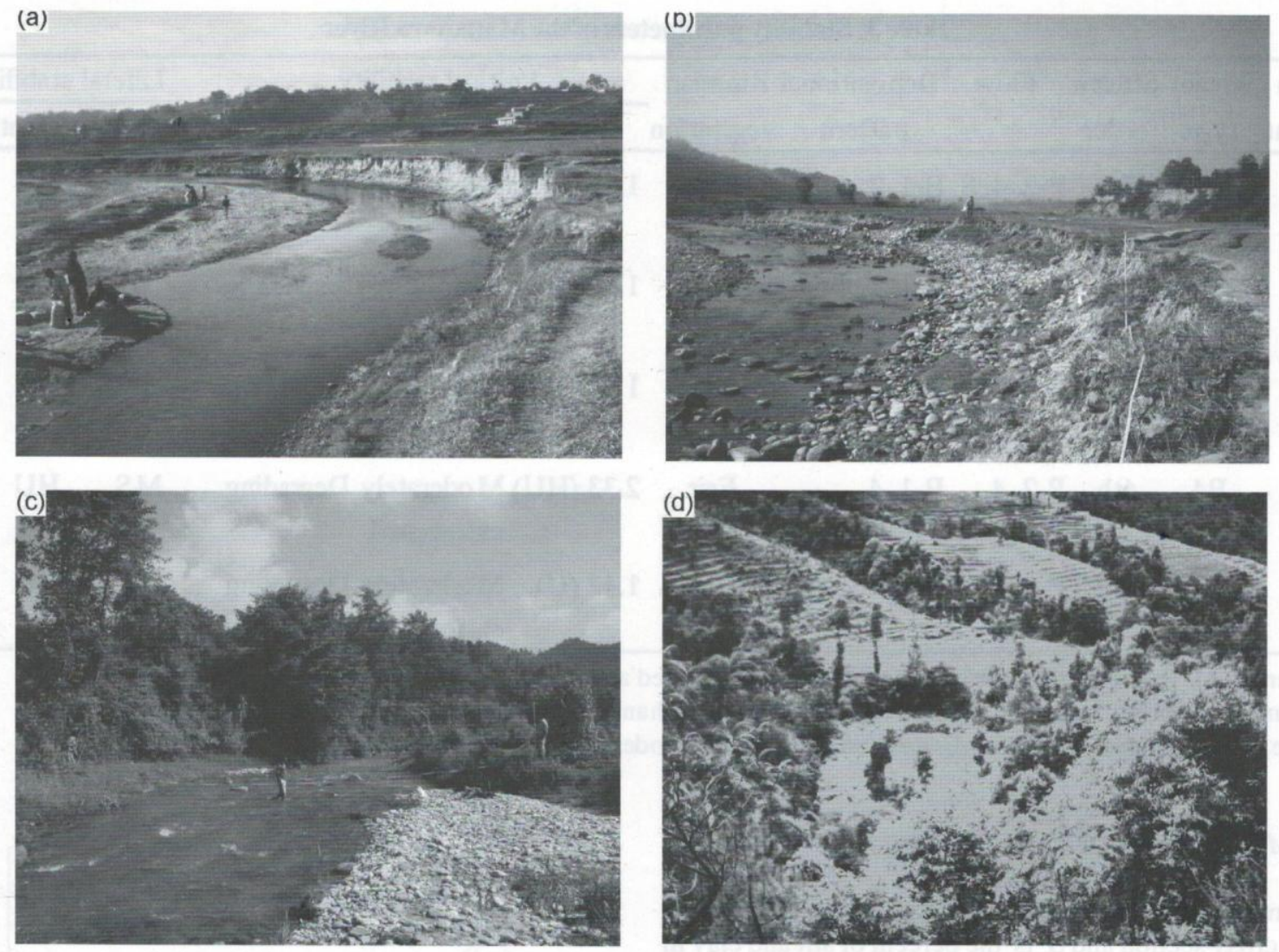

Fig. 7: Downstream views showing riparian vegetation, stream sediment and bank erosion: (a) Segment 3, (b) Segment 3, (c) Segment 4 at Sankhu and (d) Segment 5.

$$
\tau *_{c i}=0.0834\left(d_{i} / \hat{d}_{s 50}\right)^{-0.872}
$$

where $\tau_{c i}^{*}$ is a threshold dimensionless shear stress required to entrain $\mathrm{d}_{\mathrm{i}}$ of the riverbed material and $d_{s 50}$ is a median grain diameter of subsurface bed or bar material.

In gravelly streams the $\tau^{*}{ }_{c i}$ value may ranges from 0.02 to 0.25 , and for the ratio $d_{i} / d_{s 50}$ greater than $4.2, \tau^{*}{ }_{c i}$ becomes 0.02 but it may be as low as 0.01 for an eroding stream (Andrew 1983). In this instance, $d_{i}$ in Equations (4) and (5) was replaced by $d_{90}$ as we are concerned with the threshold dimensionless shear stress for the bed material of coarse 10th percentile, and then parameters were calculated (Table 1).

The calculated $\tau_{i}^{*}$ from Equation (4) ranges from 0.067 to 0.298 . In all the five segments of the Manahara River, dimensionless shear stress values are significantly greater than the calculated $\tau^{*}{ }_{c i}$ that extends from 0.02 to 0.14 , suggesting that the bankfull flow is capable of mobilising the riverbed material as large as the 90th percentile fraction. Considering this condition, the threshold bankfull depth $D$, and threshold slope $S_{t}$ required to initiate the movement of $d_{i}$ are expressed as:

$$
D_{t}=\left(1.65 \tau^{*}{ }_{c i} d_{i}\right) / S
$$

where $D$ is the existing depth at bankfull and $S$ is the existing slope.

The existing depths and slopes in all the segments (Table 1) are significantly greater than the calculated threshold depths ( 0.03 to $0.34 \mathrm{~m}$ ) and slopes $(0.001$ to $0.047 \mathrm{~m} / \mathrm{m})$. This indicates that $d_{90}$ can be entrained even in lower depths and slopes than the existing ones. It therefore suggests that bed materials in every segment of the Manahara River are prone to entrainment and transport, but it does not necessarily mean that the degradation occurs in every segment. Because erosion occurs only if the supply of sediment from the upstream is less than that transported away from the bed by the flow. As stable gravel bed stream can not be maintained at Shields constant greater than 0.08 (Andrew 1984) the bed materials of Segments 1 and 5 are unstable (Table 1).

\section{F versus $M$ relationship}

Aggradation/degradation potential of the Manahara River was evaluated using Schumm's (1963) relationship, F $=255 \mathrm{M}^{-1.08}$, where $\mathrm{F}$ and $\mathrm{M}$ factors are defined as:

$$
F=W_{b k f} / D_{b k f}
$$


Naresh Kazi Tamrakar and Ramita Bajracharya

Table 3: Stability parameters of the Manahara River

\begin{tabular}{|c|c|c|c|c|c|c|c|c|c|c|}
\hline \multirow{2}{*}{$\begin{array}{l}\text { Stream } \\
\text { segment }\end{array}$} & \multirow{2}{*}{$\begin{array}{r}\text { Stream } \\
\text { type }\end{array}$} & \multirow{2}{*}{$\begin{array}{c}\text { Stream } \\
\text { order }\end{array}$} & \multirow{2}{*}{${ }^{\mathrm{a}}$ Flow } & \multicolumn{2}{|c|}{${ }^{\mathrm{b}}$ Depositional Riparian } & \multicolumn{3}{|c|}{ Vertical stability } & \multirow{2}{*}{\multicolumn{2}{|c|}{ Lateral stability }} \\
\hline & & & & pattern & vegetation & BHR & ER & Condition & & \\
\hline 1 & F4 & 5 th & $\mathrm{P}-2,4,8$ & B- $1,2,4$ & Poor & $1.63(\mathrm{HU})$ & entrenched & Aggrading & MS & $\mathrm{HU}$ \\
\hline 2 & $\mathrm{C} 4$ & 5 th & $\mathrm{P}-2,4$ & B- $1,2,4$ & Poor & $1.30(\mathrm{U})$ & $\begin{array}{l}\text { Slightly } \\
\text { entrenched }\end{array}$ & Aggrading & $\mathrm{U}$ & $\mathrm{HU}$ \\
\hline 3 & $\mathrm{C} 4$ & 5 th & P-2, 4 & B- $1,2,4$ & Poor & $1.18(\mathrm{MU}$ & $\begin{array}{l}\text { Slightly } \\
\text { entrenched }\end{array}$ & Aggrading & $\mathrm{U}$ & HU \\
\hline 4 & B4 & 4 th & P- 2,4 & B- 1,4 & Fair & $2.33(\mathrm{HU})$ & $\begin{array}{l}\text { Moderately } \\
\text { entrenched }\end{array}$ & Degrading & MS & $\mathrm{HU}$ \\
\hline 5 & B4 & $3 r d$ & P- 2,4 & B- 1,4 & Good & $1.42(\mathrm{U})$ & $\begin{array}{l}\text { Moderately } \\
\text { entrenched }\end{array}$ & Degrading & $\mathrm{S}$ & HU \\
\hline
\end{tabular}

${ }^{\text {a }} \mathrm{P}=\mathrm{Perennial}, \mathrm{P}-2=$ storm flow dominated, $\mathrm{P}-4=$ spring fed and $\mathrm{P}-\mathrm{\gamma}=$ flow altered by development;

${ }^{\mathrm{b}} \mathrm{B}=\mathrm{Bar}, \mathrm{B}-1$ = point bars, B-2 = point bars wit hfew mid-channel bars and B-4 = side bars; HU = highly unstable, $\mathrm{U}=$ unstable, $\mathrm{MU}=$ moderately unstable, $\mathrm{MS}=$ moderately stable and $\mathrm{S}=$ st able

$$
M=\left[\left(S_{c} \cdot W_{b k f}\right)+\left(S_{b} \cdot 2 D_{b k f}\right)\right] /\left(W_{b k f}+2 D_{b k f}\right)
$$

where $\mathrm{S}_{c}$ is the percent of silt and clay in wetted perimeter of riffle cross-section and $\mathrm{S}_{\mathrm{b}}$ is the percent of silt and clay in bar material.

Using the plot of $\mathrm{F}$ versus $\mathrm{M}$ factors (Fig. 8), in which Segments 1,2, and 3 plot on the aggrading field and Segments 4 and 5 plot on the degrading field, 3rd- and fourth-order streams have degradation potential, while the fifth-order stream has aggradation potential.

\section{Plan-form change and meandering geometry relationship}

A comparison of the measurement results with the topographic map $(1: 25,000)$ of 1995 and the recent river mapping at 1:10,000 scale in 2006 has shown that the fifthorder segment of the Manahara River has modified its meander geometry significantly in past 11 years (Fig. 9). The total meander belt area has increased by $8 \%$, of which it has reduced by $31 \%$ at Segment 1 and has increased by $24 \%$ in the upstream region (Table 4). The average meander belt width has changed from 230 to $303 \mathrm{~m}$, accounting for an increase of belt width by $32 \%$. The average shifting of meander bend axis approaches $156 \mathrm{~m}$, showing a maximum shift of $243 \mathrm{~m}$ in the region of Segment 2. The overall shifting pattern is a wandering of a large wavelength of the meander belt axis with a significant right bankwards shifting in the regions of Segments 1 and 3, and the left bankwards shifting in Segment 2. The meander belt shifting has not only occurred laterally but also towards downstream by erosion at cut banks and deposition at point bars. The meander wavelength has also increased by $25 \%$. The meander belt axis has increased by only $2.7 \%$. Channel shifting in a short period

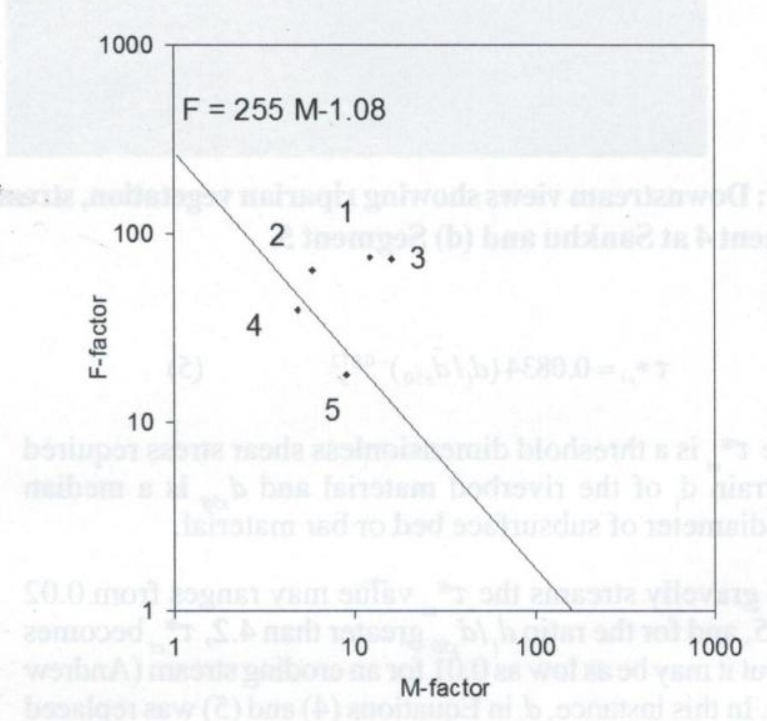

Fig. 8: $\mathrm{F}$ versus M-factor showing aggrading/degrading potential of the Manahara River segments

results probably because of increased and systemwide instability generated in a watershed level.

Many regional and plan-form relationships have been formulated for a large number of natural and artificial streams by various researchers. For instance, $\mathrm{L}_{\mathrm{m}}=10.9 \mathrm{~W}^{1.01}$ (Leopold and Wolman 1960) and $\mathrm{W}_{\mathrm{blt}}=4.4 \mathrm{~W}^{1.12}$ (Williams 1986), where $\mathrm{L}_{\mathrm{m}}$ is a meander length, $\mathrm{W}$ is a bankfull width, and $\mathrm{W}_{\text {blt }}$ is a meander belt width. These relationships were used as references, in order to find out deviations of existing stream stability. In Figs. 10a and b, both relationships are positive. In Fig. 10a, Segments 2, 3 and 4 plot farther, indicating stability 
Fluvial environment and existing stability condition of the Manahara River

Table 4: Meander geometry or planform modification of the Manahara River

\begin{tabular}{l|c|c}
\hline \multicolumn{1}{c|}{ Meander geoemtry } & Previous channel & Existing channel \\
\hline Meander belt area $\left(\mathrm{km}^{2}\right)$ & 3.17 & 3.41 \\
\hline Increase of meander belt area (\%) & & 8 \\
\hline Decrease of meander belt area in Segment 1(\%) & & 31 \\
\hline Increase of meander belt area in upstream segments (\%) & & 24 \\
\hline Average W blt (m) & 230 & 303 \\
\hline Increase of average Wblt (\%) & & 32 \\
\hline Decrease of Wblt in Segment 1 (\%) & & 43 \\
\hline Increase of Wblt in upstream segments (\%) & & 54 \\
\hline Average lateral shift of meander belt axis(m) & & 156 \\
\hline Maximum lateral shift of meander belt axis (m) & & 243 \\
\hline Meander belt axis length (km) & 15.4 & 15.9 \\
\hline Increase of meander belt axis length (\%) & & 2.7 \\
\hline Average Lm (m) & 440 & 550 \\
\hline Increase of average Lm(\%) & & 25 \\
\hline
\end{tabular}

deviations in their meander length. In Fig. 10b, Segments 2 , 4 , and 5 plot away from the curve indicating a deviation of stability in their meander belt width.

\section{Channel evolution model}

Table 5 indicates evolutionary scenarios of the segments of the Manahara River, which were recognised by analysing the cross-sections of individual segments and existing condition of the river. Comparing with the Simon's (1989) six-stage channel evolution models, the fifth-order segment can be represented by stage-V (aggrading), fourth-order stream by stage-IV (degrading and widening), and fifth-order stream by stage-III (degrading).

Although Segment 1 is aggrading, it has a decreasing tendency of W/D ratio and $\mathrm{K}$, and therefore may change to the ' $G$ ' stream type upon more entrenchment and channel constriction due to encroachment of banks. However, it is difficult to predict trend of the river as it may depend on the magnitude of anthropogenic disturbances. Segments 2 and 3 ('C4' streams) are aggrading with notable bank instability and lateral accretion. They may potentially transfer to ' $\mathrm{C} 4$ ' stream types with enhanced W/D ratio and slopes, but decreased MWR. If downstream disturbing factors influence the stream, the ' $\mathrm{C} 4$ ' stream types may evolve into the 'F4' types. Segment 4 that is degrading and widening may evolve to the 'F4' stream type on persistence of widening and degradation. Segment 5 is a degrading stream that may modify to the ' $G$ ' stream type upon extension of degradation.

\section{DISCUSSIONS}

Based on the geomorphologic analyses, 'F4' and 'C4' stream types are aggrading and 'B4' types are degrading wherein the third- and fourth-order streams are degrading, while more matured fifth-order river is aggrading. Stream flow is often competent in transporting bed materials because boundary shear stress and Shields number exceed critical dimensionless shear stress in every segment. Bank erosion, aggradation and plan-form change in fifth-order stream, and degradation in third- and fourth-order streams exhibit systemwide instability, which is perhaps induced by imbalance of discharge against sediment load and size. We do not yet have long term record of discharge and sediment load to draw inference about change in these regimes against watershed development and other changes directly influencing peak flows of the river. However, the increased bankfull discharge probably contributes huge sediment load in downstream portion of the river having very gentle slopes. With reduced slope, sedimentation in growing point bars of 'C4' and 'F4' stream types accelerates lateral shifting and planform changes.

The large magnitude of meander belt width shift and meander length propagation in 'C4' stream types represents a high magnitude of river wandering and plan-form changes, which must be the impact of systemwide instability. On the other hand the 'F4' stream type is little entrenched with increased BHR and reduced plan-form change. Excavation of construction material upstream of F4-stream perhaps induces these changes. Riverbed mining is extensive during high flow period. During this period, after the excavation of sediments from riverbeds, downstream flows become deficient in load. The load thus required is achieved by eroding riverbed and banks. When the bank is protected, the bed erosion may become effective. In this context, the upstream disturbance induces instability in downstream segments. This is comparable to the existing situation in the Bishnumati River (Tamrakar 2004) but the scenarios in the 

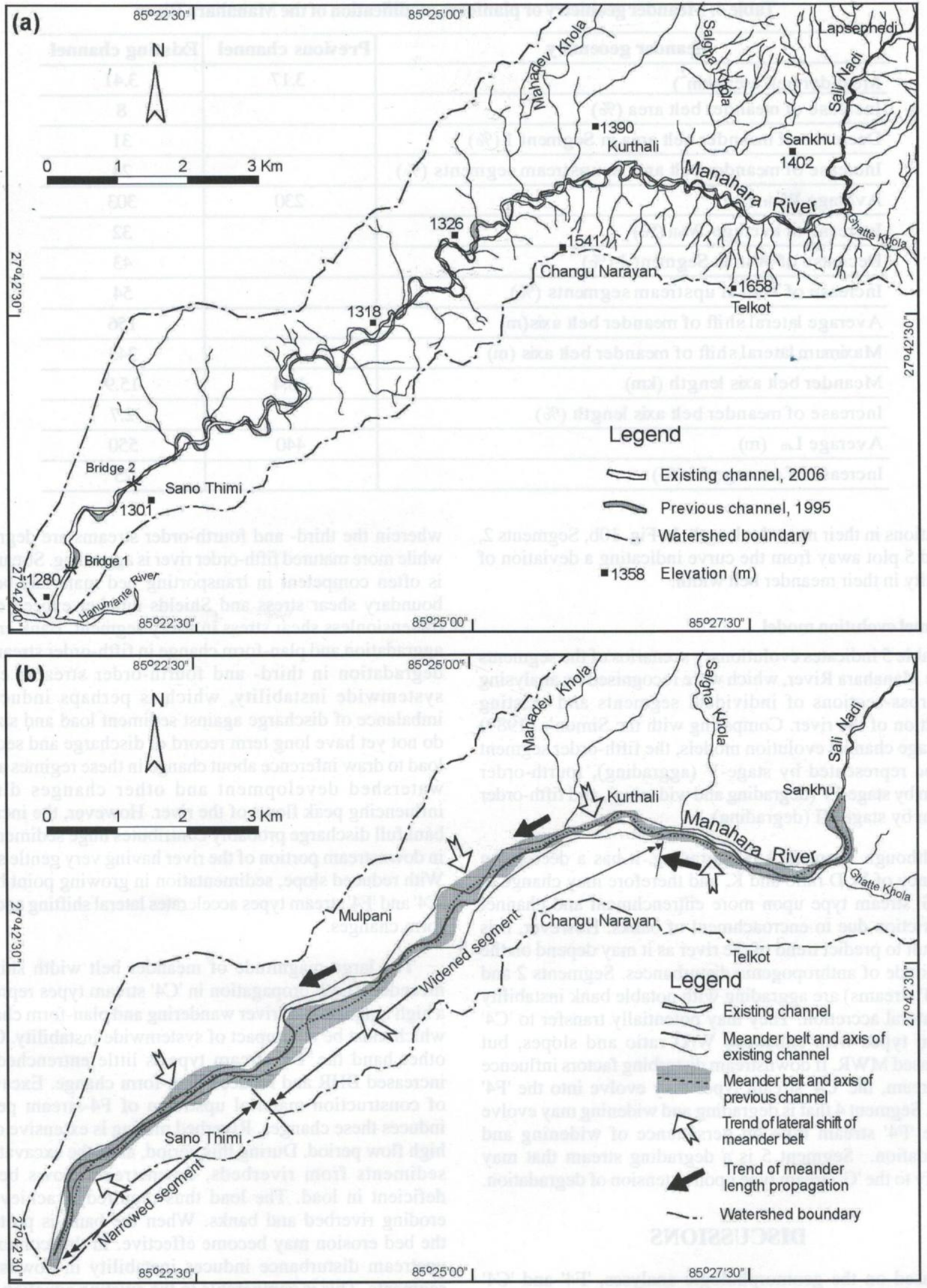

Fig. 9: Stream meander geometry changes of the Manahara River: (a) the existing river (in 2006) and previous river (1:20,000 topomaps1995), and (b) interpretive map showing previous and existing meander belts and shifting trends 
Fluvial environment and existing stability condition of the Manahara River

Table 5: Channel evolution model and evolutionary scenarios of the Manahara River

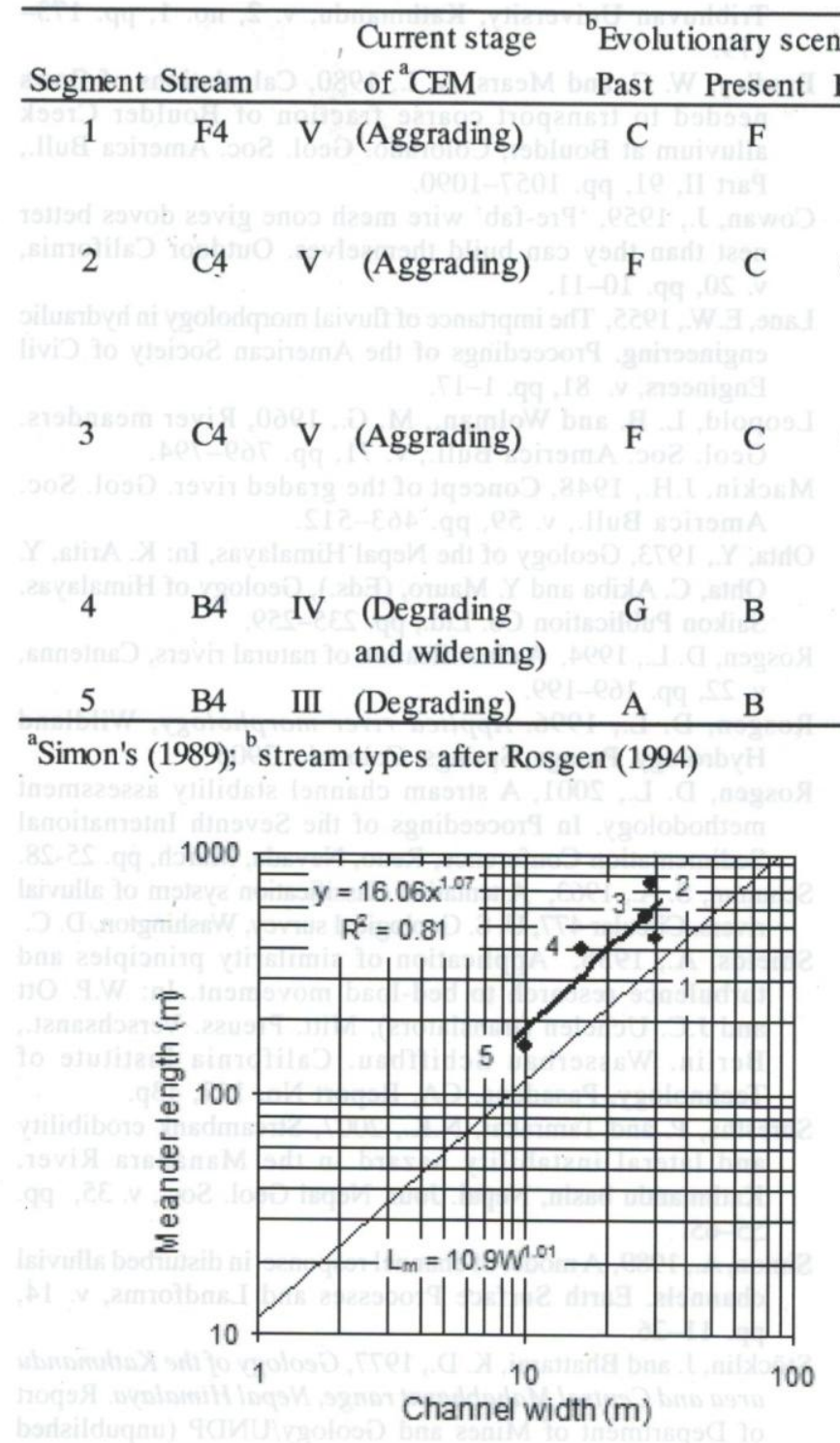

Remarks

\begin{tabular}{|c|c|c|c|c|c|c|c|}
\hline \multirow[b]{2}{*}{ Segment } & \multirow[b]{2}{*}{ Stream } & \multirow{2}{*}{\multicolumn{2}{|c|}{$\begin{array}{l}\text { Current stage } \\
\text { of }{ }^{\mathrm{a}} \mathrm{CEM}\end{array}$}} & \multicolumn{3}{|c|}{ Evolutionary scenarios } & \multirow[t]{2}{*}{ Remarks } \\
\hline & & & & Past & Present & Future & \\
\hline 1 & F4 & $\mathrm{V}$ & (Aggrading) & $\mathrm{C}$ & F & G & $\begin{array}{l}\text { With constriction of channel it may not accrete } \\
\text { much laterally, W/D ratio and K decreases with } \\
\text { aggradation }\end{array}$ \\
\hline 2 & C4 & $\mathrm{V}$ & (Aggrading) & $\mathrm{F}$ & sansi & Cbar & $\begin{array}{l}\text { With bank instability W/D ratio and slope increases, } \\
\text { K and MWR decreases, bar deposition and } \\
\text { bank erosion may accelerate; with increasing } \\
\text { downstream disturbance, C may change to } \mathrm{F}\end{array}$ \\
\hline 3 & $\mathrm{C4}$ & V & (Aggrading) & $\mathrm{F}$ & C & Cbar & $\begin{array}{l}\text { W/D ratio and slope increases, K and MWR } \\
\text { decreases, bar deposition and bank erosion } \\
\text { may accelerate; with rapidly growing downstream } \\
\text { disturbance, } C \text { may change to } \mathrm{F}\end{array}$ \\
\hline 4 & B4 & IV & $\begin{array}{l}\text { (Degrading } \\
\text { and widening) }\end{array}$ & G & B & $\mathrm{F}$ & Incision and widening of valley \\
\hline 5 & B4 & III & (Degrading) & A & B & G & Incision of valley \\
\hline
\end{tabular}

Fig. 10: Meander geometry relationships showing stability of the Manahara River. The coordinates that do not plot close to the predicted curve (Leopold and Wolman 1960) may indicate stream instability.

'F4' stream type are not worse than ones existing in the Bishnumati River.

The basinwide causes of systemwide instability can include changes in land use pattern that increase peak discharge and development of knick points due to tectonic dislocation of mountains and hills in the Manahara watershed. Besides, vegetation clearing due to increased built-up areas in upstream regions and grazing of banks, encroachment of banks for cultivation, constriction of flow, and river channel mining may be additional causes for systemwide instability. But a validation of a particular cause is necessary as several factors disturb the Manahara River in different ways and extent. If the anthropogenic disturbances can be reduced, and the upper watershed area can be managed for discharge and sediment load, the stability condition of the river can be improved in order to reduce accelerated stream bank erosion and related channel adjustment leading to instability.

\section{CONCLUSIONS}

Segments 1, 2, 3, 4 and 5 of the Manahara River are classified based on morphological characteristics in to ' $\mathrm{F} 4$ ', 'C4', 'C4', 'B4', and 'B4' stream types, respectively. The stream segments of ' $\mathrm{F} 4$ ' and ' $\mathrm{C} 4$ ' types are potentially aggradational and those of 'B4' type are potentially degradational. 
Systemwide instability exists in the Manahara River as reflected by incision, aggradation, and plan-form changes. An average meander belt axis shift of $143 \mathrm{~m}$, a belt width expansion by $32 \%$ in 11 years of period, and a deviation of meander geometry of the segments from stability support the existence of systemwide instability.

The 'B4' type streams are in stage III and IV, at the zone of incision whereas the ' $\mathrm{C} 4$ ' and ' $\mathrm{F} 4$ ' streams are at stage $\mathrm{V}$ in the zone of deposition.

Basinwide factors are the major causes of systemwide instability. Anthropogenic activities, watershed developments, encroachment of stream banks, and riverbed mining have notable inputs. The continuation of riverbed mining upstream and downstream of ' $F 4$ ' stream types may degrade the stream and this degradation may propagate upstream leading to the development of more entrenched segments that change into the ' $\mathrm{C} 4$ ' to ' $\mathrm{F} 4$ ' stream types.

It is necessary to minimise anthropogenic disturbances and to establish a riparian vegetation buffer zone $(30 \mathrm{~m}$ wide on either bank) to reduce lateral shifting and accelerated stream bank erosion especially in 'C4' types. Similarly, riverbed excavation should be discouraged. Establishment of gauging stations is recommended for generating longterm information on nature of peak discharge and sediment load in the Manahara River.

\section{ACKNOWLEDGEMENTS}

Authors are thankful to Prof. P. C. Adhikary, Head of Central Department of Geology for providing laboratory facility. Authors thank P. Shrestha for assistance in field survey.

\section{REFERENCES}

Adhikari, B. and Tamrakar, N.K., 2006, Bank instability and erosion problems in Bishnumati River, Kathmandu, Nepal, Jour. Nepal Geol. Soc., v. 34, pp. 109-116.

Aldridge, B. N. and Garrett, J.M., 1973, Roughness coefficients for stream channels in Arizona, U.S. Geological Survey OpenFile Report, U. S. Geological Survey.

Andrews, E. D., 1983, Entrainment of gravel from natural sorted riverbed material. Geol. Soc. America Bull., v. 94, pp. 12251231.

Andrews, E. D., 1984, Bed-material entrainment and hydraulic geometry of gravel-bed rivers in Colorado. Geol. Soc. America Bulletin, v. 97, pp. 1012-1023.

Bajracharya, K. R., 2001, Geology of Bhaktapur-Nagarkot area. M. Sc. Thesis submitted to Central Department of Geology, Tribhuvan University, Kathmandu, Nepal, 76 p.

Bajracharya, R. and Tamrakar, N.K., 2007, Environmental status of Manahara River, Kathmandu, Nepal. Bull. Department Geology, v. 10, pp. 21-32.
Bajracharya, S. R., 1992, Fluvial system of Kathmandu valley in relation to neotectonics. Bull. Department Geology, Tribhuvan University, Kathmandu, v. 2, no. 1, pp. 173179.

Bradley, W. C. and Mears, A. I., 1980, Calculations of flows needed to transport coarse fraction of Boulder Creek alluvium at Boulder, Colorado. Geol. Soc. America Bull., Part II, 91, pp. 1057-1090.

Cowan, J., 1959, 'Pre-fab' wire mesh cone gives doves better nest than they can build themselves. Outdoor California, v. 20 , pp. $10-11$.

Lane, E.W., 1955, The imprtance of fluvial morphology in hydraulic engineering. Proceedings of the American Society of Civil Engineers, v. 81, pp. 1-17.

Leopold, L. B. and Wolman,, M. G., 1960, River meanders. Geol. Soc. America Bull., v. 71, pp. 769-794.

Mackin, J.H., 1948, Concept of the graded river. Geol. Soc. America Bull., v. 59, pp. 463-512.

Ohta, Y., 1973, Geology of the Nepal Himalayas, In: K. Arita, Y. Ohta, C. Akiba and Y. Mauro, (Eds.), Geology of Himalayas. Saikon Publication Co. Ltd., pp. 235-259.

Rosgen, D. L., 1994, A classification of natural rivers, Cantenna, v. 22 , pp. $169-199$.

Rosgen, D. L., 1996. Applied river morphology, Wildland Hydrology, Pasoga, Springs, Colorado, 390p.

Rosgen, D. L., 2001, A stream channel stability assessment methodology. In Proceedings of the Seventh International Sedimentation Conference, Reno, Nevada, March, pp. 25-28.

Schumm, S. A., 1963, A tentative classification system of alluvial rivers. Circular 477, U. S. Geological survey, Washington, D. C.

Shields, A., 1936, Application of similarity principles and turbulence research to bed-load movement. In: W.P. Ott and J.C. Uchelen (translators), Mitt. Preuss. Verschsanst., Berlin. Wasserbau Schiffbau. California Institute of Technology, Pasadena. CA, Report No. 167, 43p.

Shrestha, P. and Tamrakar, N.K., 2007, Streambank erodibility and lateral instability hazard in the Manahara River, Kathmandu basin, Nepal. Jour. Nepal Geol. Soc., v. 35, pp. $55-65$.

Simon, A., 1989, A model of channel response in disturbed alluvial channels. Earth Surface Processes and Landforms, v. 14, pp. 11-26.

Stöcklin, J. and Bhattarai, K. D., 1977, Geology of the Kathmandu area and Central Mahabharat range, Nepal Himalaya. Report of Department of Mines and Geology/UNDP (unpublished report), $86 \mathrm{p}$.

Tamrakar, N. K., 2004, Disturbances and instabilities in the Bishnumati River corridor, Kathmandu basin, JUSAN, v. 9, pp. Issue 16, pp. 7-18.

Williams, G. W., 1986, River meanders and channel size. Jour. Hydrology, v. 88, pp. 147-164.

Wolman, M. G., 1954. A method of sampling coarse river bed material. Trans. American Geophysical Union, v. 35, pp. 951-956.

Yoshida, M. and Igarashi, Y., 1984, Neogene to quaternary lacustrine sediments in the Kathmandu Valley, Nepal, Jour. Nepal Geol. Soc., Spec. Issue, v. 4, pp. 73-100. 